\title{
Assessment of Three Antimicrobial Residue Concentrations in Broiler Chicken Droppings as a Potential Risk Factor for Public Health and Environment
}

\author{
Karina Yévenes ${ }^{1}$, Ekaterina Pokrant ${ }^{1}$, Fernando Pérez ${ }^{1}$, Ricardo Riquelme ${ }^{1}$, Constanza Avello ${ }^{1}$, \\ Aldo Maddaleno ${ }^{2}$, Betty San Martín ${ }^{2}$ and Javiera Cornejo ${ }^{1, *(1)}$ \\ 1 Department of Preventive Medicine, Faculty of Veterinary and Animal Sciences, University of Chile, \\ Av. Santa Rosa, La Pintana, Santiago 11735, Chile; kariyevenescoa@gmail.com (K.Y.); \\ katiavalerievna@ug.uchile.cl (E.P.); fernandocamilo.pm@gmail.com (F.P.); \\ ricardo.riquelme@uchile.cl (R.R.); coniavello@gmail.com (C.A.) \\ 2 Laboratory of Veterinary Pharmacology, Faculty of Veterinary and Animal Sciences, University of Chile, \\ Av. Santa Rosa, La Pintana, Santiago 11735, Chile; amaddaleno@veterinaria.uchile.cl (A.M.); \\ bsmartin@uchile.cl (B.S.M.) \\ * Correspondence: jacornej@uchile.cl; Tel.: +56-2-2978-5630
}

Received: 19 November 2018; Accepted: 13 December 2018; Published: 21 December 2018

\begin{abstract}
Tetracyclines, sulfonamides and amphenicols are broad spectrum antimicrobial drugs that are widely used in poultry farming. However, a high proportion of these drugs can be excreted at high concentrations in droppings, even after the end of a therapy course. This work intended to assess and compare concentrations of florfenicol (FF), florfenicol amine (FFa), chlortetracycline (CTC), 4-epi-chlortetracycline (4-epi-CTC), and sulfachloropyridazine (SCP) in broiler chicken droppings. To this end, 70 chickens were housed under controlled environmental conditions, and assigned to experimental groups that were treated with therapeutic doses of either $10 \% \mathrm{FF}, 20 \% \mathrm{CTC}$, or $10 \%$ SCP. Consequently, we implemented and designed an in-house validation for three analytical methodologies, which allowed us to quantify the concentrations of these three antimicrobial drugs using liquid chromatography coupled to mass spectrometry (LC-MS/MS). Our results showed that FF and FFa concentrations were detected in chicken droppings up to day 10 after ceasing treatment, while CTC and 4-epi-CTC were detected up to day 25. As for SCP residues, these were detected up to day 21. Noticeably, CTC showed the longest excretion period, as well as the highest concentrations detected after the end of its administration using therapeutic doses.
\end{abstract}

Keywords: antimicrobial residues; chlortetracycline; florfenicol; sulfachloropyridazine; chicken droppings; LC-MS/MS

\section{Introduction}

Antimicrobials are routinely used to treat clinical livestock diseases, as well as to control common disease events, or even as animal growth promoters [1]. Though the latter use is not allowed in many countries worldwide, in some still continue using them for prophylaxis and as growth promoters' purposes [2,3]. Tetracyclines and sulfonamides are some of the most frequently used antimicrobial classes in animal production throughout the world [4]. Additionally, drugs from the amphenicol class are used exclusively in the veterinary field, especially florfenicol (FF) [5]. These antimicrobials are extensively used in poultry farming for treating several diseases, such as black head disease, salmonellosis, pullorum disease, coccidiosis, omphalitis, and fowl typhoid disease [6]. According to 
some reports, it is in poultry farms from developing countries where antimicrobial drugs are being used more heavily [7], with India and Asian countries showing an expected use growth of at least $124 \%$ by year 2030 [8].

Some researchers have provided evidence that animals excrete 30 to $90 \%$ of antimicrobial drugs after its administration, either as the unmetabolized original drug or as their active metabolites [9-12]. This evidence agrees with findings from other researchers who reported detecting high concentrations of antimicrobials in faeces from several production animals. In particular, these researchers found significant evidence of tetracyclines, sulfonamides, and amphenicols in droppings from broiler chickens and manure from cattle and swine with drug concentrations that ranged from $1.4 \mu \mathrm{g}$ to $300 \mathrm{mg}$ of drug per $\mathrm{kg}$, or L of faeces [13-17].

As FF and chlortetracycline (CTC) are partially transformed into their main active metabolites-florfenicol amine (FFa) and 4-epi-chlortetracycline (4-epi-CTC), respectively-these are also used as markers for residues of these antimicrobials [18,19]. Contrarily, sulfachloropyridazine (SCP) only undergoes minor metabolisation into N-4-acetylsulfonamide, and this metabolite shows poor antimicrobial activity by itself, hence only the original drug is quantifiable [20].

Broiler litter is comprised of poultry droppings, spilled food, and feathers on top of the actual bedding material, as well as the microbiota that develops within this substrate [21]. Several classes of antimicrobials have been detected in this by-product—especially fluoroquinolones, sulfonamides, and tetracyclines [22] —hence turning litter into an important source of resistant bacteria and resistance genes [23-25]. One possible use for these litter is as an ingredient for cattle feeds, which results in passive reintroduction of pathogens and antimicrobial drugs into animals [26,27]. Another widely common use is as organic fertilizers [28-30], thus broiler litter has also become one of the main routes for entry of antimicrobials and resistance genes into the environment [31-34]. These findings are highly significant in light of the estimated 11 and 14 million tonnes of litter reported by big poultry producers, such as Brazil and the United States of America, respectively-usually recycled to use it as organic fertilizers [23,35].

Ongoing release of antimicrobial residues only partially explains their detection in the environment, because it is also a consequence of the prolonged persistence of these drugs in Nature. In particular, tetracyclines are significantly more persistent than other drugs, resulting in higher concentrations in the environment and especially on soils [36,37]. Meanwhile, sulfonamides residues show lower persistence in the environment but some researchers have reported that these migrate down to deeper layers in the soil, reaching aquifers, and some of their metabolites exhibit greater toxicity than the parental drug [36,38]. Similarly, low persistence in the environment has been reported for FF residues, which are degraded by hydrolysis, photolysis, and other mechanisms $[39,40]$. Such persistence of antimicrobial residues is greatly relevant as some researchers have reported that residues are absorbed and accumulated by crop plant species [41,42].

The presence of these drugs in the environment can result in ecological disturbances and phytotoxicological effects $[37,43]$. Specifically, some studies have revealed how toxic levels of residues from amphenicols, tetracyclines, and sulfonamides can impact sprouting and growth rates of crop plants $[44,45]$, as well as on growth, reproductive parameters, and lethality of aquatic organisms [46-48].

Bearing in mind that antimicrobials are massively used nowadays, as well as its presence in animal faeces, it is clear that this situation becomes a risk factor for both public health and environment-due to the presence of residues in both foods and nature, as well as the possibility of pathogens developing resistance to antimicrobials [12,22]. Consequently, in this work we intended to expand the knowledge regarding the spread of drugs designed for veterinary use. To this end, we administered therapeutic doses of pharmaceutical formulations of FF, CTC, and SCP to groups of broiler chickens, followed by assessing residues concentration for these drugs in their droppings by liquid chromatography coupled to tandem mass spectrometry (HPLC MS/MS). 


\section{Materials and Methods}

\subsection{Experimental Animals}

Broiler chickens from the Ross ${ }^{\circledR} 308$ genetic line were used to study each antimicrobial $(\mathrm{N}=70$ per group) and were housed in battery cages under controlled environment conditions $\left(25 \pm 5{ }^{\circ} \mathrm{C}\right.$, $50-60 \%$ relative humidity). Birds were provided with ad libitum access to water and non-medicated food that was formulated to cover the nutritional requirements recommended for the breed by the genetic company. This food was tested to ensure it was free of antimicrobial residues using an HPLC MS/MS method.

Two groups of birds were assigned for each antimicrobial drug, one experimental and the other a control group. Experimental groups were treated with commercial formulations and received therapeutic doses of 10\% FF (30 mg/kg/day for 5 days), $20 \%$ CTC ( $50 \mathrm{mg} / \mathrm{kg} /$ day for 7 days), and $10 \% \mathrm{SCP}(30 \mathrm{mg} / \mathrm{kg} /$ day for 5 days). On the other hand, control groups received no antimicrobial drugs, and all of these groups were sampled at seven different times after ceasing treatment with each drug.

The European Medicines Agency recommended some criteria to calculate experimental group sizes, which were deemed appropriate for this work and implemented. These recommendations were detailed in the Note for Guidance EMA/CVMP/SWP/735325/2012 regarding "Approach towards harmonization of withdrawal periods" [49].

Animal housing met all regulations of animal welfare, as approved by the Bioethics Committee from the Faculty of Veterinary and Animal Sciences of the University of Chile, which were outlined in resolution 03-2013 and dated on 11th of November of 2013. These recommendations were based on Directive 2010/63/EU on the protection of animals used for scientific purposes [50].

\subsection{Collection of Samples}

Group samples were collected from dropping boards that were placed below the wire mesh floor of each cage. Different zones of these trays were sampled for each sampling day, and then pooled before storing them at $-20^{\circ} \mathrm{C}$ within labelled plastic bags while waiting for further processing, analyte extraction and chromatographic analysis.

\subsection{Quantification}

\subsubsection{Reagents}

All solvents used in this work were HPLC-grade quality. Standard florfenicol and florfenicol amine solutions of certified purity $(99.8 \%)$ were used to analyse and quantify those analytes. The Internal Standard (IS) was chloramphenicol- $d_{5}\left(C A F-d_{5}\right)$ of certified purity $(97 \%)$. All standards were manufactured by Sigma-Aldrich ${ }^{\circledR}$ (Merck KgaA, Darmstadt, Germany).

Standard solutions of chlortetracycline-hydrochloride (CTC) and 4-epi-chlortetracycline (4-epi-CTC) of certified purity (95.6\%) were used for the analysis and quantification of these analytes. Additionally, isotopic tetracycline- $\mathrm{d}_{6}\left(\mathrm{TC}-\mathrm{d}_{6}\right)$ of certified purity $(>80 \%)$ was used for the internal standard. These standards were manufactured by Dr. Ehrenstorfer Gmbh (LGC Standards, Middlesex, UK) and Toronto Research Chemicals (Toronto, ON, Canada), respectively.

A standard solution of SCP of certified purity $(99.7 \%)$ was used to analyse and quantify residues of this drug, and a standard of sulfamethazine-phenyl- ${ }^{13} \mathrm{C}_{6}$ hemihydrate (SMZ) of certified purity $(99.9 \%)$ was used for the internal standard. These standards were manufactured by Sigma-Aldrich ${ }^{\circledR}$ (Merck KgaA, Darmstadt, Germany). 


\subsubsection{Sample Preparation, Extraction and Clean-Up}

All samples were initially homogenized with a spoon before collecting $2 \mathrm{~g}$ of droppings in a $50 \mathrm{~mL}$ polypropylene tube. Then, every experimental and control sample was spiked with the appropriate internal standard for each antimicrobial drug, before proceeding to extract and clean them (Figure 1).

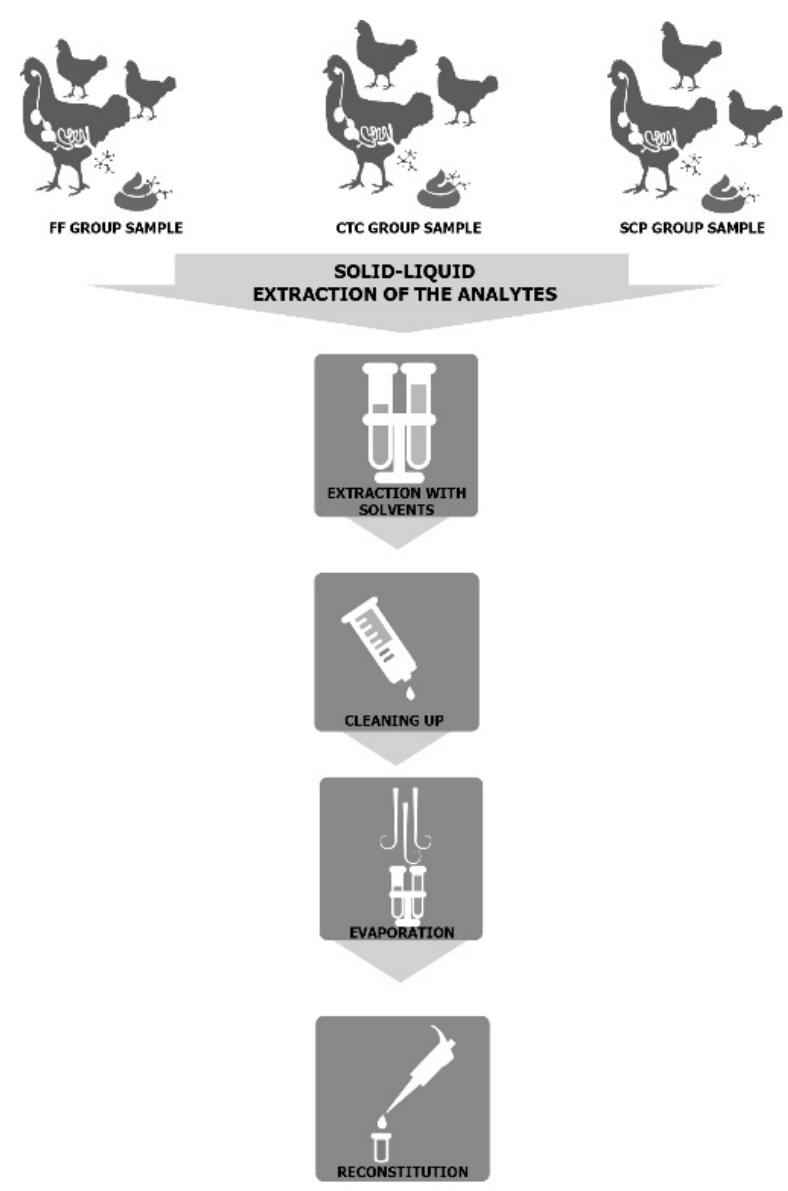

Figure 1. Solid-liquid extraction of FF, CTC, and SCP analytes from group samples of broiler chicken droppings.

Florfenicol and Florfenicol Amine

In each tube, $10 \mathrm{~mL}$ of HPLC water and $10 \mathrm{~mL}$ of acetone were added to these samples before they were agitated, sonicated, and centrifuged. The resulting supernatant was sieved through glass wool and $33 \mathrm{~mm}$ Millex ${ }^{\circledR}$ filters (Merck \& Co., Darmstadt, Germany) with $0.22 \mu \mathrm{m}$ polyvinylidene fluoride (PVDF) membranes, as it was transferred to another $50 \mathrm{~mL}$ polypropylene tube where it was mixed with $7 \mathrm{~mL}$ of dichloromethane. Tubes were agitated, sonicated and centrifuged again, and the upper phase of the solution was discarded. Then, OASIS ${ }^{\mathrm{TM}}$ HLB $^{\circledR}$ (Waters Corp., Milford, MA, USA) extraction columns were conditioned with $6 \mathrm{~mL}$ of an acetone/dichloromethane solution (7:3 ratio) before proceeding to elute the samples with $8 \mathrm{~mL}$ of methanol. Afterwards, samples were evaporated under mild nitrogen flow in a water bath $\left(45 \pm 5{ }^{\circ} \mathrm{C}\right)$. Finally, samples were reconstituted in $700 \mu \mathrm{L}$ of a methanol/water solution (7:3 ratio). This methodology was adapted from techniques previously published by other authors [51-53].

Chlortetracycline and 4-epi-Chlortetracycline

First, $4 \mathrm{~mL}$ of EDTA-Mcllvaine buffer solution and $1 \mathrm{~mL}$ of acetonitrile were added to each sample in a $50 \mathrm{~mL}$ polypropylene tube and then agitated, sonicated, and centrifuged. The resulting supernatant was sieved through glass wool while being transferred to another $50 \mathrm{~mL}$ polypropylene tube. Then, 
$13 \mathrm{~mL}$ of EDTA-Mcllvaine buffer solution were added to this tube, mixed, and passed through OASIS ${ }^{\mathrm{TM}}$ HLB $^{\circledR}$ (Waters Corp.) solid phase extraction columns. These columns were previously conditioned with $5 \mathrm{~mL}$ of methanol and $5 \mathrm{~mL}$ of HPLC-grade water. Afterwards, these columns were eluted using $5 \mathrm{~mL}$ of methanol, and the elute was evaporated under mild nitrogen flow in a water bath $\left(45 \pm 5^{\circ} \mathrm{C}\right)$. Finally, samples were reconstituted in $200 \mu \mathrm{L}$ of methanol and $300 \mu \mathrm{L}$ of HPLC-grade water. This method was adapted from the methodology published by Berendsen et al. [54].

\section{Sulfachloropyridazine}

First, $10 \mathrm{~mL}$ of ethyl acetate and $2 \mathrm{~g}$ of sodium sulfate anhydrous were added to each sample in a $50 \mathrm{~mL}$ polypropylene tube and then agitated, sonicated, and centrifuged. The resulting supernatant was poured into another $50 \mathrm{~mL}$ polypropylene tube and extracted again twice (using $10 \mathrm{~mL}$ of ethyl acetate), collecting and pooling all of these supernatants each time. This pool was concentrated down to a volume of $15 \mathrm{~mL}$ by evaporating it in a water bath $\left(45 \pm 5^{\circ} \mathrm{C}\right)$ under a mild nitrogen flow. Then, the concentrated samples were passed through SCX ${ }^{\circledR}\left(\mathrm{J}\right.$. T. Baker ${ }^{\circledR}$, Avantor ${ }^{\mathrm{TM}}$ Performance Materials, LLC, Center Valley, PA, USA) cationic sulfonic acid solid phase extraction columns that had been previously conditioned with $6 \mathrm{~mL}$ of hexane and $6 \mathrm{~mL}$ of ethyl acetate. A solution of $10 \mathrm{~mL}$ of methanol/ammonia (48.5:1.5 mL ratio) was used for elution. The resulting elute was then evaporated under a mild nitrogen flow in a water bath $\left(45 \pm 5^{\circ} \mathrm{C}\right)$ and reconstituted in $500 \mu \mathrm{L}$ of mobile phase solution (phase A and B in a 15/85 proportion). This methodology was adapted from a method previously published by other authors [55-57]. All reconstituted samples, for every antimicrobial drug, were transferred to $1.5 \mathrm{~mL}$ Eppendorf tubes, which were centrifuged and sieved through a Millex ${ }^{\circledR}$ filter while being poured into labelled autosampler vials that were read using LC-MS/MS.

\subsubsection{Instrumental Analysis}

An Agilent ${ }^{\circledR}$ series 1290 liquid chromatography system (Agilent, Santa Clara, CA, USA) coupled to an API 5500 (AB Sciex ${ }^{\circledR}$, Framingham, MA, USA) triple quadrupole mass spectrometer were used to detect and quantify FF and FFa. The analytical column was a Synergi ${ }^{\mathrm{TM}} 4-\mu \mathrm{m}$ fusion RP $80 \AA, 50 \times 2.0 \mathrm{~mm}$ (Torrance, CA, USA), and the chromatographic separation used a mobile phase of $0.1 \%$ acetic acid in water (phase A) and $0.1 \%$ acetic acid in water/methanol (1:9 ratio, phase B). The flow rate was $350 \mu \mathrm{L} \mathrm{min}{ }^{-1}$, the gradient elution was $25 \%$ phase solvent $\mathrm{A}$, and $75 \%$ phase solvent $\mathrm{B}$, the injection volume was $2 \mu \mathrm{L}$, and temperature was set at $37^{\circ} \mathrm{C}$.

Meanwhile, an Agilent ${ }^{\circledR}$ series 3200 liquid chromatograph device coupled to an API 4000 $\left(\mathrm{AB}\right.$ Sciex $\left.{ }^{\circledR}\right)$ triple quadrupole mass spectrometer were used to detect and quantify CTC and 4-epi-CTC. The analytical column was a Sunfire ${ }^{\mathrm{TM}} \mathrm{C}_{18} 3.5 \mu \mathrm{m}, 150 \times 2.1 \mathrm{~mm}$ (Waters Corp.), and the chromatographic separation used a mobile phase of $0.1 \%$ formic acid in water (phase A) and $0.1 \%$ formic acid in methanol (phase B). The flow rate was $0.2 \mu \mathrm{L} \mathrm{min}{ }^{-1}$, the gradient elution was $78 \%$ phase solvent $\mathrm{A}$, and $22 \%$ phase solvent $\mathrm{B}$, the injection volume was $25 \mu \mathrm{L}$, and temperature was set at $30^{\circ} \mathrm{C}$.

Lastly, an Agilent ${ }^{\circledR}$ series 1200 liquid chromatograph device coupled to an API 3200 (AB Sciex ${ }^{\circledR}$ ) triple quadrupole mass spectrometer were used to detect and quantify SCP. The analytical column was a Symmetry ${ }^{\mathrm{TM}} \mathrm{C}_{8} 3.5 \mu \mathrm{m}, 100 \times 2.1 \mathrm{~mm}$ (Waters Corp.) and the chromatographic separation used a mobile phase of $0.1 \%$ formic acid in methanol (phase A) and $0.1 \%$ formic acid in water (phase B). The flow rate was $200 \mu \mathrm{L} \mathrm{min}{ }^{-1}$, the gradient elution was $45 \%$ phase solvent $\mathrm{A}$, and $55 \%$ phase solvent $\mathrm{B}$, the injection volume was $20 \mu \mathrm{L}$, and temperature was set at $35^{\circ} \mathrm{C}$.

Finally, the Analyst ${ }^{\circledR}$ version 1.6.2 software package (AB SCIEX) was used for the chromatographic integration of all samples. Table 1 lists the monitored ion masses. 
Table 1. Monitored ion masses.

\begin{tabular}{ccc}
\hline Analyte & Precursor Ion (Da) & Fragment Ion (Da) \\
\hline FF & 356.0 & 336.0 \\
FFa & 248.0 & 230.0 \\
CAF- $_{5}$ & 326.0 & 157.0 \\
CTC & 479.0 & 444.0 \\
4 epi-CTC & 479.0 & 154.0 \\
TC-d & 451.0 & 416.0 \\
SCP & 284.9 & 155.9 \\
SMZ & 285.1 & 124.1 \\
\hline
\end{tabular}

\subsection{In-House Validation}

The in-house validation protocol was designed following the recommendations from the European Union Commission Decision 2002/657/EC [58]. To ensure that this methodology was suitable for detecting residues of each antimicrobial drug in chicken droppings, the protocol assessed several performance parameters. In particular, the protocol evaluated specificity, limit of detection (LOD), limit of quantification (LOQ) and curve linearity. For each antimicrobial drug, the limit of detection (LOD) was established based on a signal-to-noise ratio greater than 3:1. (averaged from the results of 20 samples, fortified at the LOD). As for the Limit of Quantification (LOQ), it was determined by calculating the sum of these values with the product of 1.64 times their standard deviation. Lastly, linearity was calculated using blank samples that were fortified using five different and equidistant concentrations.

\section{Results}

\subsection{In-House Validation of Analytical Methodologies}

In regard to specificity, we observed no interference from blank samples within the interest region where elution of the analyte is expected (Figure 2). Specifically, the LOD for FF, FFa, CTC, 4-epi-CTC, and SCP were of 50, 50, 20, 20, and $10 \mu \mathrm{g} / \mathrm{kg}$, respectively. Meanwhile, the LOQ was set at 52.2, 60.5, $22.5,22.9$, and $12.6 \mu \mathrm{g} / \mathrm{kg}$ for FF, FFa, CTC, 4-epi-CTC, and SCP, respectively. As for the calibration curves, these were fortified at concentrations of 50, 100, 200, 300 and $500 \mu \mathrm{g} / \mathrm{kg}$ for FF and FFa; 20, 40, 60, 80 and $100 \mu \mathrm{g} / \mathrm{kg}$ for CTC and 4-Epi-CTC; and 10, 20, 40, 80 and $100 \mu \mathrm{g} / \mathrm{kg}$ for SCP. All of these curves showed a linear response and their $\mathrm{R}^{2}$ was greater than 0.99 .

\subsection{Assessment of Antimicrobial Concentrations in Broiler Chicken Droppings}

\subsubsection{Detection and Quantification of FF and FFa in Broiler Chicken Droppings}

Quantification results showed that FF and FFa concentrations declined by $76 \%$ in droppings between days 5 and 10 after ceasing treatment, down to a final concentration of $136.23 \mu \mathrm{g} / \mathrm{kg}$ on the second sampling point (see Figure 2). After day 10, no residues were detected. Table 2 details concentrations of FF and FFa detected for each sampling point after ceasing antimicrobial treatment. 
Table 2. FF and FFa residue concentrations in chicken broiler droppings after treatment with a commercial formulation, by sampling point.

\begin{tabular}{cccc}
\hline Sampling Point & $\begin{array}{c}\text { Days after } \\
\text { Ceasing Treatment }\end{array}$ & Age (Days) & $\begin{array}{c}\text { Final Concentration of } \\
\text { FF + FFa }(\boldsymbol{\mu g} / \mathbf{K g})\end{array}$ \\
\hline 1 & 5 & 15 & 568.35 \\
2 & 10 & 20 & 136.23 \\
3 & 15 & 25 & $<\mathrm{LOD}$ \\
4 & 20 & 30 & $<\mathrm{LOD}$ \\
5 & 25 & 35 & $<\mathrm{LOD}$ \\
6 & 30 & 40 & $<\mathrm{LOD}$ \\
7 & 35 & 45 & $<\mathrm{LOD}$ \\
\hline
\end{tabular}
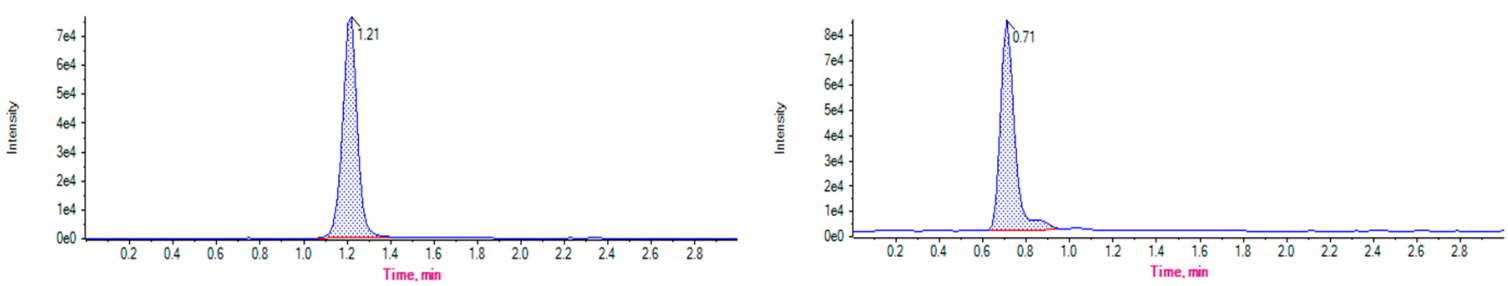

(A)
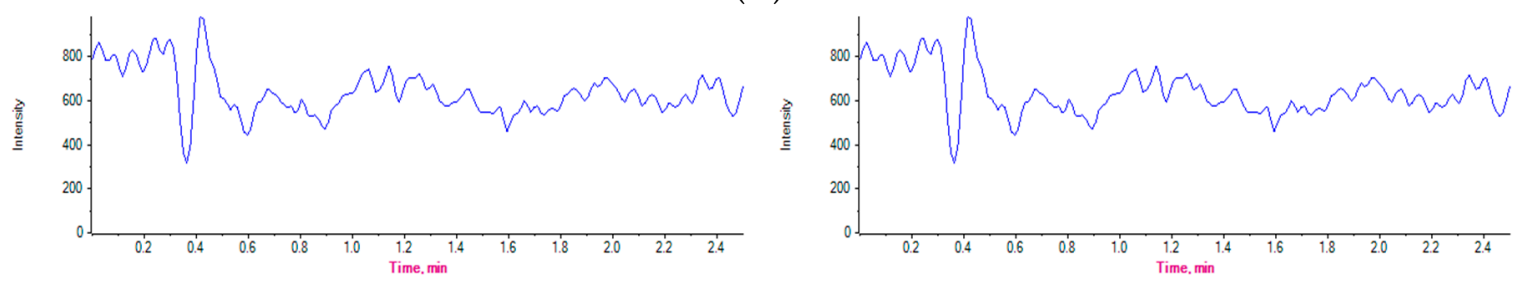

(B)
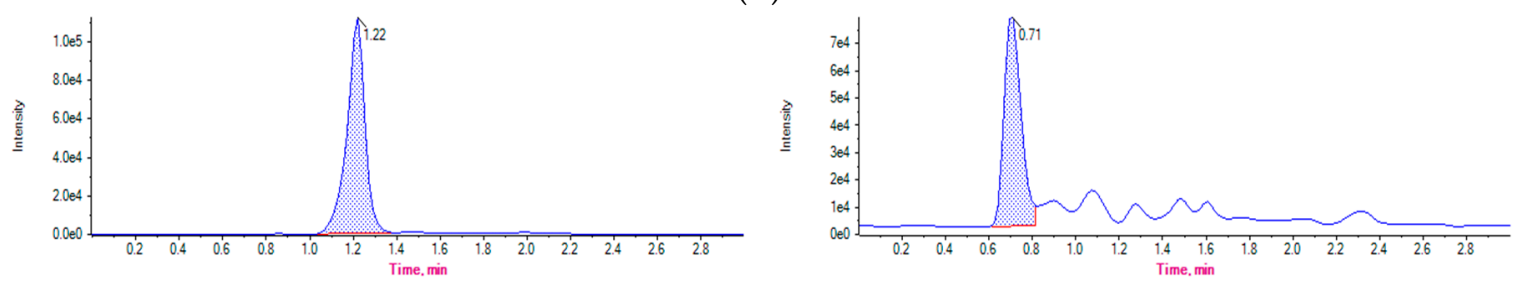

(C)

Figure 2. Representative chromatograms from (A) Certified standard injection of FF (left) and FFa (right), (B) Blank samples, free of residues of FF (left) and FFa (right), (C) Droppings samples with residues of FF (left) and FFa (right), from experimental animals at day 10 after ceasing treatment (sampling point 2).

\subsubsection{Detection and Quantification of CTC and 4-epi-CTC in Broiler Chicken Droppings}

CTC and 4-epi-CTC residues were detected at every sampling point. These concentrations declined steadily over time, up to day 18 after ceasing treatment, which was the inflexion point when residue concentrations began rising up again and reaching a value of $179.45 \mu \mathrm{g} / \mathrm{kg}$ at the seventh sampling point. Table 3 lists these concentrations as detected for each sampling point. 
Table 3. CTC and 4-epi-CTC in droppings from broiler chickens treated with a commercial formulation, by sampling point.

\begin{tabular}{cccc}
\hline Sampling Point & $\begin{array}{c}\text { Days after } \\
\text { Ceasing Treatment }\end{array}$ & Age (Days) & $\begin{array}{c}\text { Final Concentration of } \\
\text { CTC + 4-epi-CTC }(\boldsymbol{\mu g} / \mathbf{K g})\end{array}$ \\
\hline 1 & 5 & 25 & 665.82 \\
2 & 8 & 28 & 368.17 \\
3 & 11 & 31 & 258.4 \\
4 & 15 & 35 & 136.88 \\
5 & 18 & 38 & 106.47 \\
6 & 21 & 41 & 112.01 \\
7 & 25 & 45 & 179.45 \\
\hline
\end{tabular}

\subsubsection{Detection and Quantification of SCP in Broiler Chicken Droppings}

SCP residues in droppings declined steadily at each sampling point and were detected only up to day 21 after ceasing treatment. In particular, concentrations decreased by $94 \%$ between days 2 and 21 , reaching a final value of $24.261 \mu \mathrm{g} / \mathrm{kg}$ on the fourth sampling point. Table 4 details concentrations of SCP detected for each sampling point after ceasing antimicrobial treatment.

Table 4. SCP concentration in droppings from broiler chickens who were treated with a commercial formulation, by sampling point.

\begin{tabular}{cccc}
\hline Sampling Point & $\begin{array}{c}\text { Days after } \\
\text { Ceasing Treatment }\end{array}$ & Age (Days) & $\begin{array}{c}\text { SCP Concentration } \\
(\boldsymbol{\mu g} / \mathbf{K g})\end{array}$ \\
\hline 1 & 2 & 11 & 382.242 \\
2 & 5 & 14 & 124.748 \\
3 & 10 & 19 & 38.186 \\
4 & 21 & 30 & 24.261 \\
5 & 32 & 41 & $<\mathrm{LOD}$ \\
6 & 34 & 43 & $<\mathrm{LOD}$ \\
7 & 36 & 45 & $<\mathrm{LOD}$ \\
\hline
\end{tabular}

\section{Discussion}

Lately, faeces of production animals have become an important analytical matrix, mostly due to the fact that high concentrations of the antimicrobials commonly administered can be excreted by this route [12]. Therefore, analyzing these drugs in faeces might become an important tool to collect more information in regard to the development of antimicrobial resistance within the intestine of animals and about the dissemination of antimicrobials in the environment, as well as also helping on the effort to monitor the usage trends for antimicrobial drugs, whether it is legally, illegally, or off-label [59].

The finding of FF residues up to day 10 after ceasing treatment might be a consequence of its pharmacokinetic properties, such as its fast and efficient absorption by the gastrointestinal system, its large volume of distribution, and its good tissue penetration [60,61]. Not long ago, [62] identified FF and FFa residues in broiler chicken feathers up to day 40 after ceasing treatment, detecting concentrations that exceeded $100 \mu \mathrm{g} / \mathrm{kg}$. Similarly, [63] detected them in chicken claws up to day 25 after ceasing treatment. Thus, the fact that these residues could be identified in our work up to day 10 after ceasing treatment might be a consequence of such prolonged bioaccumulation within feathers and claws, as well as the rapid excretion of these metabolites [64].

As for SCP, residue concentrations in droppings decreased steadily up to day 21 after ceasing treatment, reaching values of $24.261 \mu \mathrm{g} / \mathrm{kg}$ of droppings. Meanwhile, a study found that SCP residues could be detected in feathers up to day 36 after ceasing treatment [65], stating that this drug can bioaccumulate for extended periods in feathers of broiler chickens-a phenomenon that correlates with its wide distribution over peripheral tissues [66] — and that could explain why these residues could only be detected up to day 21 after ceasing treatment. Additionally, pharmacokinetic properties 
could explain why the excretion period is so narrow for SCP: they are mainly eliminated by the renal route, metabolites are excreted faster than the unmetabolized drug, and the low urinary $\mathrm{pH}$ favours their reabsorption, hence prolonging their excretion half-lives [6,67].

Faecal excretion of CTC might be attributed to it undergoing an entero-hepatic cycle, where the drug is reabsorbed from the intestine after its excretion in the bile. Several important changes can be noticed when a significant fraction of the drug enters this kind of recirculation mechanism, such as an extension of its half-life and the elimination period via the renal route. Moreover, CTC is excreted mainly by kidneys and follows a slow process $[6,68]$. Likewise, some studies propose that CTC is eliminated more slowly in broiler chickens than other analogous tetracyclines [18].

We are currently not aware of any study reporting on CTC and 4-epi-CTC depletion in feathers, claws or edible tissues in broiler chickens who received therapeutic doses of this antimicrobial. However, one study detected OTC and 4-epi-OTC concentrations in claws from broiler chickens up to day 19 after ceasing treatment [69]. Similarly, the same research group found residue concentrations of these analytes in feathers up to day 46 after ceasing treatment [70]. Consequently, systemic recirculation of CTC residues from claws and feather might explain the increase observed on CTC and 4-epi-CTC concentrations on days 21 and 25 after ceasing treatment. Nonetheless, in spite of the similarity between the chemical structures of OTC and CTC, some studies in humans and animals suggest that CTC is excreted differently, hence assuming that absorption, distribution, and excretion are similar between different animal species might be an oversimplification [18]. Therefore, to clarify whether the increase in CTC and 4-epi-CTC over the last days was a consequence from systemic recirculation, we should study CTC depletion in several organs of chickens, as well as measuring plasma concentrations of its metabolites. These results were also reported before by our research group in Cornejo et al. [71].

All group samples were thoroughly homogenized to ensure they were appropriately representative of the experimental birds. However, despite it must be consider that this represent a limitation for the study as it does not allow the calculation of a group mean and standard deviation over time, pooling samples offered a global perspective about residue concentrations when birds receive therapeutic doses of antimicrobial drugs.

As the main component of broiler litter is chicken droppings, this by-product presents a potential danger as it might reintroduce antimicrobial residues in the food chain and the environment-especially when used as an organic fertilizer. Furthermore, faeces are stored at room temperature before using them as organic fertilizers, and this impacts differently the persistence of antimicrobial drugs depending on drug class and kind of faeces [59]. These authors also state that in the case of broiler droppings, SCP is slightly persistent, unlike CTC, which persists for much longer periods showing a $\mathrm{DT}_{50}$ and $\mathrm{a} \mathrm{DT}_{90}$ of 18 and 61 days, respectively.

Based on the results observed in this work, CTC could impact public health and the environment more severely than the other antimicrobials we studied, as it is excreted for a longer period and at higher concentrations following a therapeutic dose. Also, CTC is widely used both in veterinary and human medicine, it shows a moderate persistence within organic fertilizers during storage, as well as greater stability, persistence, and toxicity in the environment than other drugs [1,37,43,59]. Evidently then, the potential consequences of its use in animal farming could be alarming.

\section{Conclusions}

The LC-MS/MS methods we implemented and in-house validated for this work allowed us, in a reliable and specific manner, to detect and quantify FF, FFa, CTC, 4-epi-CTC, and SCP analytes in droppings from broiler chickens. Our data showed that these birds excreted these drugs up to days 10 for FF and FFa, day 21 for SCP, and day 25 for CTC and 4-epi-CTC. Overall, CTC would be the antimicrobial drug that poses a greater risk to public health and the environment.

This study is a pioneering work in regard to determining antimicrobial residues in faeces from animals that have been treated therapeutically, thus it contributes significantly to an informed decision-making process that may lead to regulations intended for managing these drugs rationally 
within the context of animal farming, as well as the practice of using animal faeces as a source of organic fertilizers for crops of human interest.

Author Contributions: Data curation, E.P.; Formal analysis, A.M.; Funding acquisition, J.C.; Methodology, K.Y., F.P., R.R. and C.A.; Project administration, J.C.; Resources, B.S.M.; Supervision, J.C.; Writing-original draft, K.Y.; Writing-review \& editing, J.C.

Funding: This research was funded by the IAEA Research contract 22180, under the Coordinated Research Project D52041.

Acknowledgments: The authors would like to thank Rodrigo Gambra and the laboratory technicians of the Veterinary Pharmacology Laboratory (FARMAVET), of the Faculty of Veterinary and Animal Sciences, University of Chile.

Conflicts of Interest: The authors declare no conflict of interest.

\section{References}

1. Landers, T.F.; Cohen, B.; Wittum, T.E.; Larson, E.L. A Review of Antibiotic Use in Food Animals: Perspective, Policy, and Potential. Public Health Rep. 2012, 127, 4-22. [CrossRef] [PubMed]

2. European Medicines Agency. Sales of Veterinary Antimicrobial Agents in 30 European Countries in 2015: Trends from 2010 to 2015: Seventh ESVAC Report; European Medicines Agency: London, UK, 2017; ISBN 978-92-9155-058-6.

3. Manyi-Loh, C.; Mamphweli, S.; Meyer, E.; Okoh, A. Antibiotic Use in Agriculture and Its Consequential Resistance in Environmental Sources: Potential Public Health Implications. Molecules 2018, $23,795$. [CrossRef] [PubMed]

4. World Organization for Animal Health. OIE Annual Report on the Use of Antimicrobial Agents in Animals-Better Understanding of the Global Situation; OIE: Paris, France, 2016; pp. 1-67.

5. Zhao, Q.; Wang, Y.; Wang, S.; Wang, Z.; Du, X.; Jiang, H.; Xia, X.; Shen, Z.; Ding, S.; Wu, C.; et al. Prevalence and Abundance of Florfenicol and Linezolid Resistance Genes in Soils Adjacent to Swine Feedlots. Sci. Rep. 2016, 6, 1-7. [CrossRef] [PubMed]

6. Sumano López, H.S.; Gutiérrez Olvera, L. Farmacología Clínica en aves comerciales [Clinical Pharmacology in Poultry], 4th ed.; Interamericana Mc-Graw-Hill: Mexico DF, Mexico, 2010.

7. Cuong, N.; Padungtod, P.; Thwaites, G.; Carrique-Mas, J. Antimicrobial Usage in Animal Production: A Review of the Literature with a Focus on Low- and Middle-Income Countries. Antibiotics 2018, 7, 75. [CrossRef] [PubMed]

8. Van Boeckel, T.P.; Brower, C.; Gilbert, M.; Grenfell, B.T.; Levin, S.A.; Robinson, T.P.; Teillant, A.; Laxminarayan, R. Global trends in antimicrobial use in food animals. PNAS 2015, 112, 5649-5654. [CrossRef] [PubMed]

9. Marshall, B.M.; Levy, S.B. Food Animals and Antimicrobials: Impacts on Human Health. Clin. Microbiol. Rev. 2011, 24, 718-733. [CrossRef] [PubMed]

10. Zhou, L.-J.; Ying, G.-G.; Liu, S.; Zhang, R.-Q.; Lai, H.-J.; Chen, Z.-F.; Pan, C.-G. Excretion masses and environmental occurrence of antibiotics in typical swine and dairy cattle farms in China. Sci. Total Environ. 2013, 444, 183-195. [CrossRef]

11. Carvalho, I.T.; Santos, L. Antibiotics in the aquatic environments: A review of the European scenario. Environ. Int. 2016, 94, 736-757. [CrossRef]

12. Mehdi, Y.; Létourneau-Montminy, M.-P.; Gaucher, M.-L.; Chorfi, Y.; Suresh, G.; Rouissi, T.; Brar, S.K.; Côté, C.; Ramirez, A.A.; Godbout, S. Use of antibiotics in broiler production: Global impacts and alternatives. Anim. Nutr. 2018, 4, 170-178. [CrossRef]

13. Hu, X.-G.; Yi, L.; Zhou, Q.-X.; Xu, L. Determination of Thirteen Antibiotics Residues in Manure by Solid Phase Extraction and High Performance Liquid Chromatography. Chinese J. Anal. Chem. 2008, 36, 1162-1166. [CrossRef]

14. Hou, J.; Wan, W.; Mao, D.; Wang, C.; Mu, Q.; Qin, S.; Luo, Y. Occurrence and distribution of sulfonamides, tetracyclines, quinolones, macrolides, and nitrofurans in livestock manure and amended soils of Northern China. Environ. Sci. Pollut. Res. 2015, 22, 4545-4554. [CrossRef] [PubMed] 
15. Alavi, N.; Babaei, A.A.; Shirmardi, M.; Naimabadi, A.; Goudarzi, G. Assessment of oxytetracycline and tetracycline antibiotics in manure samples in different cities of Khuzestan Province, Iran. Environ. Sci. Pollut. Res. 2015, 22, 17948-17954. [CrossRef] [PubMed]

16. Carballo, M.; Aguayo, S.; González, M.; Esperon, F.; de la Torre, A. Environmental Assessment of Tetracycline's Residues Detected in Pig Slurry and Poultry Manure. J. Environ. Prot. 2016, 07, 82-92. [CrossRef]

17. Wolters, B.; Widyasari-Mehta, A.; Kreuzig, R.; Smalla, K. Contaminations of organic fertilizers with antibiotic residues, resistance genes, and mobile genetic elements mirroring antibiotic use in livestock? Appl. Microbiol. Biotechnol. 2016, 100, 9343-9353. [CrossRef] [PubMed]

18. Anadón, A.; Gamboa, F.; Martínez, M.A.; Castellano, V.; Martínez, M.; Ares, I.; Ramos, E.; Suarez, F.H.; Martínez-Larrañaga, M.R. Plasma disposition and tissue depletion of chlortetracycline in the food producing animals, chickens for fattening. Food Chem. Toxicol. 2012, 50, 2714-2721. [CrossRef] [PubMed]

19. Orlando, E.A.; Costa Roque, A.G.; Losekann, M.E.; Colnaghi Simionato, A.V. UPLC-MS/MS determination of florfenicol and florfenicol amine antimicrobial residues in tilapia muscle. J. Chromatogr. B 2016, 1035, 8-15. [CrossRef]

20. Antibacterial Agents: Chemistry, Mode of Action, Mechanisms of Resistance, and Clinical Applications; Anderson, R.J.; Groundwater, P.W.; Todd, A.; Worsley, A. (Eds.) John Wiley \& Sons: Chichester, UK, 2012; ISBN 978-0-470-97244-1.

21. Santos Dalólio, F.; da Silva, J.N.; Carneiro de Oliveira, A.C.; Ferreira Tinôco, I.d.F.; Christiam Barbosa, R.; Resende, M.d.O.; Teixeira Albino, L.F.; Teixeira Coelho, S. Poultry litter as biomass energy: A review and future perspectives. Renew. Sust. Ener. Rev. 2017, 76, 941-949. [CrossRef]

22. Van Epps, A.; Blaney, L. Antibiotic Residues in Animal Waste: Occurrence and Degradation in Conventional Agricultural Waste Management Practices. Curr. Pollut. Rep. 2016, 2, 135-155. [CrossRef]

23. Chen, Z.; Jiang, X. Microbiological safety of chicken litter or chicken litter-based organic fertilizers: A review. Agriculture 2014, 4, 1-29. [CrossRef]

24. Ljubojević, D.; Puvača, N.; Pelić, M.; Todorović, D.; Pajić, M.; Milanov, D.; Velhner, M. Epidemiological significance of poultry litter for spreading the antibiotic-resistant strains of Escherichia coli. Worlds. Poult. Sci. J. 2016, 72, 485-494. [CrossRef]

25. Yang, Q.; Zhang, H.; Guo, Y.; Tian, T. Influence of Chicken Manure Fertilization on Antibiotic-Resistant Bacteria in Soil and the Endophytic Bacteria of Pakchoi. Int. J. Environ. Res. Public Health 2016, 13, 662. [CrossRef]

26. Van Ryssen, J.B.J. Poultry Litter as a Feedstuff for Ruminants: A South African Scene. Available online: http:/ / docplayer.net/20928569-Poultry-litter-as-a-feedstuff-for-ruminants-a-south-african-scene.html (accessed on 15 December 2018).

27. Wilkinson, K.G.; Tee, E.; Tomkins, R.B.; Hepworth, G.; Premier, R. Effect of heating and aging of poultry litter on the persistence of enteric bacteria. Poult. Sci. 2011, 90, 10-18. [CrossRef] [PubMed]

28. Marble, S.C.; Sibley, J.L.; Gilliam, C.H.; Torbert, H.A. Application of composted poultry litter as a fertilizer for landscape bedding plants. HortScience 2011, 46, 1367-1372.

29. Tewolde, H.; Sistani, K.R.; Adeli, A. Fall- and Spring-Applied Poultry Litter Effectiveness as Corn Fertilizer in the Mid-Southern United States. Agron. J. 2013, 105, 1743-1748. [CrossRef]

30. Bohara, H.; Dodla, S.; Wang, J.J.; Darapuneni, M.; Kongchum, M.; Fromme, D.D.; Harrell, D. Impacts of N-stabilizers and Biochar on Nitrogen Losses, Nitrogen Phytoavailability, and Cotton Yield in Poultry Litter-Fertilized Soils. Agron. J. 2018, 110, 2016-2025. [CrossRef]

31. Kwon, S.; Owens, G.; Ok, Y.; Lee, D.; Jeon, W.-T.; Kim, J.; Kim, K.-R. Applicability of the Charm II system for monitoring antibiotic residues in manure-based composts. Waste Manage. 2011, 31, 39-44. [CrossRef] [PubMed]

32. Massé, D.I.; Saady, N.M.C.; Gilbert, Y. Potential of biological processes to eliminate antibiotics in livestock manure: an overview. Animals 2014, 4, 146-163. [CrossRef]

33. Ruuskanen, M.; Muurinen, J.; Meierjohan, A.; Pärnänen, K.; Tamminen, M.; Lyra, C.; Kronberg, L.; Virta, M. Fertilizing with Animal Manure Disseminates Antibiotic Resistance Genes to the Farm Environment. J. Environ. Qual. 2016, 45, 488-493. [CrossRef]

34. Xie, W.-Y.; Shen, Q.; Zhao, F.J. Antibiotics and antibiotic resistance from animal manures to soil: a review: Antibiotics and antibiotic resistance. Eur. J. Soil. Sci. 2018, 69, 181-195. [CrossRef] 
35. Sanchuki, C.E.; Soccol, C.R.; de Carvalho, J.C.; Soccol, V.T.; do Nascimento, C.; Woiciechowski, A.L. Evaluation of poultry litter traditional composting process. Braz. Arch. Biol. Technol. 2011, 54, 1053-1058. [CrossRef]

36. Pan, M.; Chu, L.M. Leaching behavior of veterinary antibiotics in animal manure-applied soils. Sci. Total Environ. 2017, 579, 466-473. [CrossRef] [PubMed]

37. Grenni, P.; Ancona, V.; Barra Caracciolo, A. Ecological effects of antibiotics on natural ecosystems: A review. Microchem. J. 2018, 136, 25-39. [CrossRef]

38. Zhang, Y.; Hu, S.; Zhang, H.; Shen, G.; Yuan, Z.; Zhang, W. Degradation kinetics and mechanism of sulfadiazine and sulfamethoxazole in an agricultural soil system with manure application. Sci. Total Environ. 2017, 607-608, 1348-1356. [CrossRef] [PubMed]

39. Boxall, A.B.A. Fate of veterinary medicines applied to soils. In Pharmaceuticals in the Environment; Springer: Freiburg, Germany, 2008; pp. 165-180.

40. Martins, A.; Guimarães, L.; Guilhermino, L. Chronic toxicity of the veterinary antibiotic florfenicol to Daphnia magna assessed at two temperatures. Environ. Toxicol. Pharmacol. 2013, 36, 1022-1032. [CrossRef] [PubMed]

41. Hu, X.; Zhou, Q.; Luo, Y. Occurrence and source analysis of typical veterinary antibiotics in manure, soil, vegetables and groundwater from organic vegetable bases, northern China. Environ. Pollut. (Oxford, UK) 2010, 158, 2992-2998. [CrossRef] [PubMed]

42. Pan, M.; Chu, L. Fate of antibiotics in soil and their uptake by edible crops. Sci. Total Environ. 2017, 599, 500-512. [CrossRef]

43. Minden, V.; Deloy, A.; Volkert, A.M.; Leonhardt, S.D.; Pufal, G. Antibiotics impact plant traits, even at small concentrations. AoB Plants 2017, 9. [CrossRef]

44. Liu, F.; Ying, G.-G.; Tao, R.; Zhao, J.-L.; Yang, J.-F.; Zhao, L.-F. Effects of six selected antibiotics on plant growth and soil microbial and enzymatic activities. Environ. Pollut. (Oxford, UK) 2009, 157, 1636-1642. [CrossRef]

45. Pan, M.; Chu, L.M. Phytotoxicity of veterinary antibiotics to seed germination and root elongation of crops. Ecotoxicol. Environ. Saf. 2016, 126, 228-237. [CrossRef]

46. Park, S.; Choi, K. Hazard assessment of commonly used agricultural antibiotics on aquatic ecosystems. Ecotoxicology 2008, 17, 526-538. [CrossRef]

47. Ji, K.; Kim, S.; Han, S.; Seo, J.; Lee, S.; Park, Y.; Choi, K.; Kho, Y.-L.; Kim, P.-G.; Park, J.; et al. Risk assessment of chlortetracycline, oxytetracycline, sulfamethazine, sulfathiazole, and erythromycin in aquatic environment: are the current environmental concentrations safe? Ecotoxicology 2012, 21, 2031-2050. [CrossRef] [PubMed]

48. Kołodziejska, M.; Maszkowska, J.; Białk-Bielińska, A.; Steudte, S.; Kumirska, J.; Stepnowski, P.; Stolte, S. Aquatic toxicity of four veterinary drugs commonly applied in fish farming and animal husbandry. Chemosphere 2013, 92, 1253-1259. [CrossRef] [PubMed]

49. CVMP. Guideline on Approach towards Harmonisation of Withdrawal Periods; European Medicines Agency, Committee for Veterinary Medicinal Products: London, UK, 2016; pp. 1-37.

50. European Parliament and the Council of the European Union. Directive 2010/63/EU of 22 September 2010 of the European Parliament and of the Council on the protection of animals used for scientific purposes. Off. J. Eur. Union 2018, 276, 33-79.

51. Hormazabal, V.; Steffenak, I.; Yndestad, M. Simultaneous determination of residues of florfenicol and the metabolite florfenicol amine in fish tissues by high-performance liquid chromatography. J. Chromatogr. 1993, 616, 161-165. [CrossRef]

52. Li, J.; Ding, S.; Zhang, S.; Li, C.; Li, X.; Liu, Z.; Liu, J.; Shen, J. Residue Depletion of Florfenicol and Its Metabolite Florfenicol Amine in Swine Tissues after Intramuscular Administration. J. Agric. Food Chem. 2006, 54, 9614-9619. [CrossRef]

53. Zhang, S.; Liu, Z.; Guo, X.; Cheng, L.; Wang, Z.; Shen, J. Simultaneous determination and confirmation of chloramphenicol, thiamphenicol, florfenicol and florfenicol amine in chicken muscle by liquid chromatography-tandem mass spectrometry. J. Chromatogr. B 2008, 875, 399-404. [CrossRef]

54. Berendsen, B.J.A.; Wegh, R.S.; Memelink, J.; Zuidema, T.; Stolker, L.A.M. The analysis of animal faeces as a tool to monitor antibiotic usage. Talanta 2015, 132, 258-268. [CrossRef]

55. Hindle, R. A Validated Atmospheric Pressure Chemical Ionization Method for Analyzing Sulfonamides in Pork Muscle. 2003. Available online: http:/ / www.youngin.com/application/0411-0045EN-E.pdf (accessed on 22 December 2018). 
56. Shao, B.; Dong, D.; Wu, Y.; Hu, J.; Meng, J.; Tu, X.; Xu, S. Simultaneous determination of 17 sulfonamide residues in porcine meat, kidney and liver by solid-phase extraction and liquid chromatography-tandem mass spectrometry. Anal. Chim. Acta 2005, 546, 174-181. [CrossRef]

57. Thompson, T.S.; Noot, D.K. Determination of sulfonamides in honey by liquid chromatography-tandem mass spectrometry. Anal. Chim. Acta 2005, 551, 168-176. [CrossRef]

58. European Commission. 2002/657/EC: Commission Decision of 12 August 2002 implementing Council Directive 96/23/EC concerning the performance of analytical methods and the interpretation of results. Off. J. Eur. Union 2002, L 221, 0008-0036.

59. Berendsen, B.; Lahr, J.; Nibbeling, C.; Jansen, L.; Bongers, I.; Wipfler, E.; Van de Schans, M. The persistence of a broad range of antibiotics during calve, pig and broiler manure storage. Chemosphere 2018, 204, 267-276.

60. Anadón, A.; Martínez, M.A.; Martínez, M.; Ríos, A.; Caballero, V.; Ares, I.; Martínez-Larrañaga, M.R. Plasma and Tissue Depletion of Florfenicol and Florfenicol-amine in Chickens. J. Agric. Food Chem. 2008, 56, 11049-11056. [CrossRef]

61. Mestorino, N. Antimicrobianos en avicultura. Available online: https://www.researchgate.net/ profile/Nora_Mestorino/publication/305592763_ANTIMICROBIANOS_EN_AVICULTURA/links / 57949bbf08aeb0ffcced9cb5/ANTIMICROBIANOS-EN-AVICULTURA.pdf (accessed on 15 November 2018).

62. Cornejo, J.; Pokrant, E.; Riquelme, R.; Briceño, C.; Maddaleno, A.; Araya-Jordán, C.; San Martin, B. Single-laboratory validation of an LC-MS/MS method for determining florfenicol (FF) and florfenicol amine (FFA) residues in chicken feathers and application to a residue-depletion study. Food Addit. Contam. Part A 2016, 34, 469-476. [CrossRef]

63. Pokrant, E.; Riquelme, R.; Maddaleno, A.; San Martín, B.; Cornejo, J. Residue Depletion of Florfenicol and Florfenicol Amine in Broiler Chicken Claws and a Comparison of Their Concentrations in Edible Tissues Using LC-MS/MS. Molecules 2018, 23, 2211. [CrossRef] [PubMed]

64. Abu-Basha, E.A.H.; Gehring, R.; Al-Shunnaq, A.F.; Gharaibeh, S.M. Pharmacokinetics and Bioequivalence of Florfenicol Oral Solution Formulations (Flonicol ${ }^{\circledR}$ and Veterin ${ }^{\circledR} 10 \%$ ) in Broiler Chickens. J. Bioequiv. Availab. 2012, 4, 1-5. [CrossRef]

65. Medina Pontigo, F.J. Evaluación De La Bioacumulación De Residuos De Sulfacloropiridazina En Plumas De Pollos Broiler En Relación A Su Concentración En Tejidos Comestibles; University of Chile: Santiago, Chile, 2017.

66. Deck, D.H.; Winston, L.G. Sulfonamides, Trimethoprim and Quinolones. In Basic E Clinical Pharmacology; Katzung, B.G., Masters, S.B., Trevor, A.J., Eds.; A Lange medical book; McGraw-Hill Medical: New York, NY, USA, 2012; pp. 831-838. ISBN 978-0-07-176401-8.

67. Riviere, J.E.; Lees, P.; Elliott, J.; Clarke, C.; Anadón, A.; Baggot, D.; Brown, S.; Burka, J.; Craigmill, A.; Delatour, P.; et al. USP Veterinary Pharmaceutical Information Monographs-Antibiotics. J. Vet. Pharmacol. Ther. 2003, 26, 1-271. [CrossRef] [PubMed]

68. Lemos, M.L. Antimicrobianos que inhiben la síntesis de proteínas. In Farmacología y terapéutica veterinaria; Botana, L.M., Landoni, M.F., Martín Jiménez, T., Eds.; McGraw-Hill/Interamericana de España: Madrid, Spain, 2002; pp. 468-483. ISBN 84-486-0471-7.

69. Cornejo, J.; Pokrant, E.; Araya, D.; Briceño, C.; Hidalgo, H.; Maddaleno, A.; Araya-Jordán, C.; San Martin, B. Residue depletion of oxytetracycline (OTC) and 4-epi-oxytetracycline (4-epi-OTC) in broiler chicken's claws by liquid chromatography-tandem mass spectrometry (LC-MS/MS). Food Addit. Contam. Part A 2017, 34, 494-500. [CrossRef] [PubMed]

70. Cornejo, J.; Pokrant, E.; Krogh, M.; Briceño, C.; Hidalgo, H.; Maddaleno, A.; Araya-Jordán, C.; Martín, B.S. Determination of Oxytetracycline and 4-Epi-Oxytetracycline Residues in Feathers and Edible Tissues of Broiler Chickens Using Liquid Chromatography Coupled with Tandem Mass Spectrometry. J. Food Prot. 2017, 80, 619-625. [CrossRef]

71. Cornejo, J.; Yevenes, K.; Avello, C.; Pokrant, E.; Maddaleno, A.; San Martin, B.; Lapierre, L. Determination of Chlortetracycline Residues, Antimicrobial Activity and Presence of Resistance Genes in Droppings of Experimentally Treated Broiler Chickens. Molecules 2018, 23, 1264. [CrossRef]

(C) 2018 by the authors. Licensee MDPI, Basel, Switzerland. This article is an open access article distributed under the terms and conditions of the Creative Commons Attribution (CC BY) license (http:// creativecommons.org/licenses/by/4.0/). 